(c) American Dairy Science Association, 2004.

\title{
Automatic Milking and Grazing-Effects of Distance to Pasture and Level of Supplements on Milk Yield and Cow Behavior
}

\section{E. Spörndly and E. Wredle}

Swedish University of Agricultural Sciences (SLU),

Department of Animal Nutrition and Management,

Kungsängen Research Centre, SE-753 23 Uppsala, Sweden

\section{ABSTRACT}

In an automatic milking system, 45 cows were divided into groups that grazed on a mixed grass sward (Poa Pratensis and Festuca Pratensis) at different distances from the barn: near pasture (NP) at $50 \mathrm{~m}$ between the barn and the pasture and distant pasture (DP) at 260 $\mathrm{m}$ between the barn and the pasture. For both of these treatments, $3 \mathrm{~kg}$ of dry matter (DM) from supplementary grass silage were offered in the barn. The third treatment group grazed together under the DP treatment but was offered an ad libitum supply of grass silage in the barn $(\mathrm{DP}+\mathrm{S})$. Cows were also fed concentrates in relation to requirements (average $7 \mathrm{~kg} / \mathrm{d}$ per cow). During the period from June 5 to July 13 (Period 1 ), cows in the NP group had a higher milk yield (29.1 $\mathrm{kg})$ than did cows in the DP group $(26.4 \mathrm{~kg})$ and had a higher milking frequency compared with the other groups, 2.5 vs. 2.3 and 2.3 milkings/d, respectively. During August, cows in group DP $+\mathrm{S}$ had a lower milking frequency (2.1 milkings/d) compared with the two groups on lower supplementation (2.5 milkings/d). In Period 1, all groups spent approximately $20 \%$ of their time grazing, but after mid July groups DP and DP + S decreased the time they spent grazing to around 10\%; cows in group NP continued to graze as before. Thus, longer distances to pasture may lead to decreases in milk yield, milking frequency, and grazing time of cows in an automatic milking system. The higher level of silage supplementation (group DP $+\mathrm{S}$ ) did not result in a significantly higher milk yield compared with herdmates (DP) also grazing the more distant pasture.

(Key words: automatic milking, grazing, behavior, milk production)

Abbreviation key: $\mathbf{D P}=$ distant pasture, $\mathbf{D P}+\mathbf{S}=$ $\mathrm{DP}+$ ad libitum silage, ECM = energy-corrected milk, $\mathbf{M E}=$ metabolizable energy, $\mathbf{N P}=$ near pasture .

Received July 4, 2003.

Accepted November 26, 2003.

Corresponding author: E. Spörndly; e-mail: Eva.Sporndly@ huv.slu.se.

\section{INTRODUCTION}

In many countries, pasture and grazing are an integrated part of the milk production system. Well-managed pasture offers the cow a high quality feed at low cost. Furthermore, it may also improve the health of the cow with regard to leg and hoof disorders and decrease the number of veterinary treatments (Gustafson, 1993). In addition to being a question of animal welfare, summertime grazing for cows has also become an important issue for consumers in many countries (Mathijs, 2000).

The basic concept in automatic milking is the free choice of the cow to feed, rest, and be milked when it suits her. However, Prescott et al. (1998) found that the motivation of a cow to be milked was weak compared with their motivation to eat. Therefore, in most automatic milking systems, cows are offered concentrates in the milking unit. In many cases, cows also have to pass the milking unit or a selection gate to enter the feeding area where roughages, and in some cases more concentrates, are offered. Thus, feed is used to entice the cows to be milked.

During the pasture season, the feeding situation is completely different. As pasture can offer high quality, easily available feed in the immediate vicinity of the cow, it may be difficult to motivate the cow to walk from the pasture to the barn to be milked. Also, the cow out at pasture is no longer near the milking unit, and she has to walk some distance to reach the barn.

Compared with the indoor period, cow behavior tends to become more synchronized during the grazing season (O'Conell et al., 1989; Ketelaar-de Lauwere et al., 1999). The ideal situation during the pasture season is when cows enter and leave the barn in a steady flow day and night. Thus, cows must be encouraged to act independently. However, this may be difficult to achieve at pasture, especially when the pasture area is situated far from the barn. Pasture areas are not always situated in the immediate vicinity of the barn, and many farms have one or more paddocks more than $200 \mathrm{~m}$ from the barn, in some cases even further (van Dooren et al., 2002). In conventional systems, this is no problem as 
the animals are herded back to the barn for milking. However, when automatic milking is practiced, the animals must be motivated to independently walk between the pasture and the barn several times a day.

The effect of distance between pasture and barn on milking and visiting frequencies in an automatic milking system was studied by Ketelaar-de Lauwere et al. (2000) using 24 animals and a grazing period of $15 \mathrm{~h} /$ d. Most automatic milking systems operate with considerably more animals, as can be seen in a survey from the Netherlands (van Dooren et al., 2002). The number of animals in the barn may have an important influence on cow traffic and milking frequencies, as there will be a higher degree of competition in front of the milking unit and feeding troughs. The objective of this experiment was to study the effects of distance between barn and pasture and the effects of different levels of silage supplements on milk yield, milking frequency, and cow behavior in an automatically milked herd where passage out to the pasture was open $24 \mathrm{~h} / \mathrm{d}$ and the automatic milking system included 45 or more cows.

\section{MATERIALS AND METHODS}

\section{Animals and Barn Layout}

During the whole experiment, there were 45 to 50 cows of the Swedish Red and White breed in the barn; all were assigned to various treatment groups. The cows were of two genetic selection lines, as described by Åkerlind et al. (1999), and were mainly in mid or late lactation (average lactation $=$ wk 29) at the start of the experiment. Average milk yield was $29 \mathrm{~kg}$ energy-corrected milk (ECM)/d (Sjaunja et al., 1990), and average live weight was $580 \mathrm{~kg}$. About one-half $(51 \%)$ of the animals in the experimental group were primiparous.

The research farm where the experiments were performed had a DeLaval Voluntary Milking System (VMS; DeLaval, Tumba, Sweden). The barn layout is presented in Figure 1. The barn consisted of a resting area with 56 cubicles (also known as free stalls), two identical feeding areas, and one milking unit with a collection area. Each feeding area had 10 separate feed troughs for roughage feeding and one concentrate feeder.

Animals in the resting area had to pass the selection gates to enter the feeding area. However, cows to be milked had to pass the milking unit before they could reach the feeding area. From each feeding area, there was an exit gate leading to a cow track where cows could choose either to continue out to the pasture area or to re-enter the barn via the entrance gate. The entrance to the barn was placed before, and the exit to the pasture was placed after, the milking unit and selection gates. Thus, cows with milking permission that entered the barn could not leave the barn and return to the pasture without passing the milking unit to be milked.

\section{Treatments and Management}

The animals in each age category (primiparous and multiparous) were randomly assigned to 3 treatment groups. The treatment groups were near pasture (NP), distant pasture (DP), and distant pasture + silage (DP $+\mathbf{S}$ ); each differed with respect to the level of supplementary grass silage allowed and the distance between the barn and pasture. The pastures were mixed grass swards dominated mainly by Kentucky bluegrass (Poa Pratensis) and meadow fescue (Festuca Pratensis). The treatments and silage feeding levels are presented in Table 1.

In addition to grass silage, animals in all treatment groups were offered $1 \mathrm{~kg}$ of hay/d and concentrates. Hay was offered mainly as a structure feed with the objective of stabilizing conditions in the rumen when animals consumed large quantities of lush pasture with low fiber content. The animals received only a small amount of concentrates in the milking unit $(0.5 \mathrm{~kg})$, whereas the rest of the concentrate ration was supplied in the concentrate feeders. Each cow was offered concentrates according to requirements based on live weight and milk yield just before being let out onto pasture, assuming an intake of $130 \mathrm{~mJ}$ of metabolizable energy (ME) from roughage (i.e., pasture, supplementary hay, and silage). The concentrate allowance was kept consistent throughout the experiment.

The cows were divided into two separate groups depending on grazing area. All animals entered the barn through the same gate, but, after milking, animals grazing on NP and DP were directed to separate feeding areas via an automatic gate. From the exit gate of each feeding area, cow tracks and one-way gates led the animals to the NP and DP areas, respectively. Thus, animals in treatment groups $\mathrm{DP}$ and $\mathrm{DP}+\mathrm{S}$ grazed in the same pasture area; treatments only differed with regard to the level of supplementary silage offered in the barn. The DP was not visible from the area near the barn.

Each cow was identified with a transponder at milking, at selection gates, and at feed troughs and concentrate feeders. The amount of milk from each milking and the amounts of roughages and concentrate consumed by each individual cow on each feeding occasion were registered automatically.

Roughage feeding and concentrate allowance were controlled on an individual level. Roughage troughs and concentrate feeders were programmed, and once a cow had consumed her daily ration, the troughs or feeders were closed for further consumption for that particular 


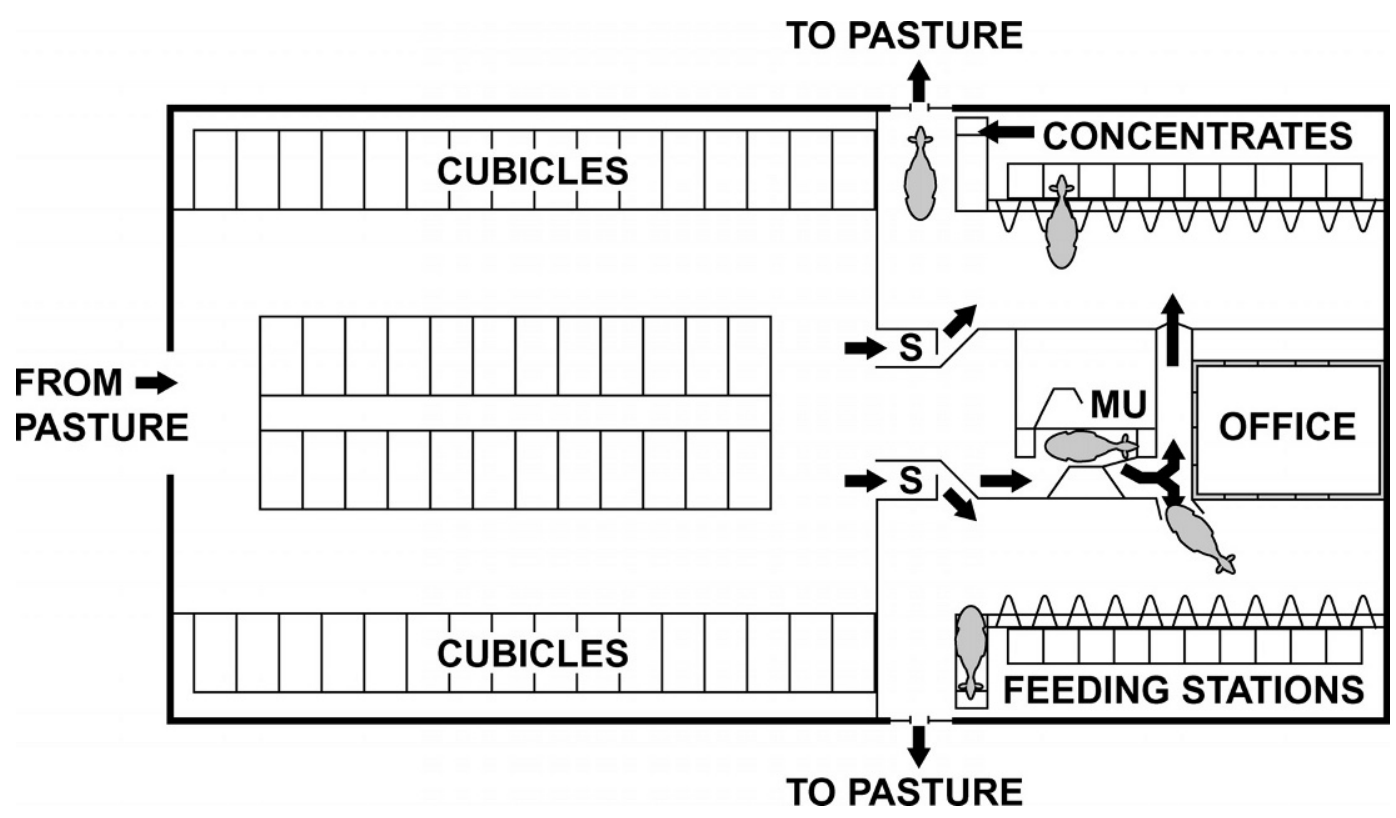

Figure 1. Barn layout. Resting area included 56 cubicles and 2 feeding areas, each with 10 roughage feeders and one concentrate feeder. Selection gates $(\mathrm{S})$ allowed passage to the feeding area for cows that were not due for milking. MU = milking unit (milking robot for automatic milking).

cow. Daily roughage and concentrate allowance was divided into 4 portions spread over 6 -h periods each day, preventing the cow from eating all of her supplements at once. Feed allowance that had not been consumed during one 6 -h period could be consumed in the following period. For concentrates, there was also a $20 \%$ carry-over of unconsumed allowance from one day to the next. The main components in the concentrates were $61 \%$ barley and oats, $23 \%$ protein feeds (soybean meal and rapeseed products), and $10 \%$ sugar beet pulp containing $12 \mathrm{~mJ}$ of $\mathrm{ME}$ and $17 \% \mathrm{CP} / \mathrm{kg}$.

Milking permission was granted $7 \mathrm{~h}$ after the latest milking with the exception of one cow that was granted permission after $6 \mathrm{~h}$ because of high cell counts in milk at experimental start $(639,000)$. At approximately 0500 and $1700 \mathrm{~h}$, cows that had not been milked during the last 12 to $14 \mathrm{~h}$ were fetched to be milked.

\section{Experimental Periods}

The experiment started in the beginning of the pasture season in mid May and lasted until the end of August. Animals were milked and weighed before the start of the pasture period, and the animals in each of the two age groups (primiparous and multiparous) were randomly assigned to 1 of the 3 treatment groups. The first 2.5 wk at pasture were used as an adaptation period to allow the cows to become accustomed to the treatments, to the different pasture areas, and to the one-way gates. Data were analyzed during two separate periods: Period 1 (June 5 to July 13) and Period 2 (August 2 to 30 ). The period in between had to be excluded from the statistical analysis because pf problems with automatic data recording. However, this did not affect the cows or treatments.

Table 1. Pasture distances, pasture allowance, and supplementary feeding of grass silage DM in the 3 treatment groups: near pasture (NP), distant pasture (DP), and DP + silage (DP + S).

\begin{tabular}{llll}
\hline & \multicolumn{3}{c}{ Treatment } \\
\cline { 2 - 4 } & $\mathrm{NP}$ & $\mathrm{DP}$ & $\mathrm{DP}+\mathrm{S}$ \\
\hline Distance to pasture, $\mathrm{m}$ & 50 & 260 & 260 \\
Most distant point $^{1}$ of pasture, $\mathrm{m}$ & 330 & 850 & 850 \\
Pasture area, ha $^{1}$ & $2.75 \rightarrow 4.0$ & $4.75 \rightarrow 6.75$ & $4.75 \rightarrow 6.75$ \\
Pasture allowance $^{1}$ & ad libitum & ad libitum & ad libitum \\
Grass silage, $\mathrm{kg}$ of $\mathrm{DM}$ & 3 & 3 & ad libitum \\
\hline
\end{tabular}

\footnotetext{
${ }^{1}$ Pasture area increased as the season progressed to ensure high pasture supply throughout the experiment.
} 
During Period 1 , there were 45 cows in the statistical analysis (22 multiparous and 23 primiparous), and during Period 2, there were 28 cows (13 multiparous and 15 primiparous). Only data from cows that were present in the barn at the beginning of the pasture season were included in the statistical analysis. A number of cows were dried toward the end of the grazing season, yielding a smaller group of animals for the statistical analysis during Period 2.

From the start of the pasture season and throughout Period 1, all animals in the experiment had access to drinking water only in the barn. During Period 2, all animals were offered drinking water both out on pasture and in the barn until the end of the experiment.

\section{Behavior Observations}

Behavior observations were performed on 30 cows, 10 in each treatment group. Apart from balancing the number of heifers and older cows, the cows were randomly selected within treatment group for behavior observations. Time sampling observations on the behavior of each cow were recorded at 15-min intervals during 6 -h periods. The observations were evenly distributed over the day and night. Altogether, 28 observation periods were made throughout the grazing season, corresponding to seven 24 -h cycles summarized as "observation days" in the results. Median dates for observation d 1 to 7 were June 15, June 21, June 26, July 3, July 9, July 24, and August 23. Thus, the main part of the observation for $\mathrm{d} 1$ to 5 took place during experimental Period 1; one observation day took place between the two experimental periods (observation d 6), and one took place during experimental Period 2 (observation d 7). Initially, $6 \mathrm{~d}$ of observation were planned, but as a change in the behavior pattern of the animals was noted during Period 2, a 7th observation day was added, giving a larger time gap between observation $\mathrm{d} 6$ and 7 .

At each 6-h session, the following observations were recorded for each animal: 1) location (feeding, milking, or resting area in the barn, cow track, and pasture), 2) position (lying down or standing up), and 3) activity (grazing, eating in barn, being milked, walking, other activities).

For each cow and behavior, the number of observations was summarized over one observation day and divided by the total number of observations made on the animal that day, thus obtaining the percentage spent on each observed activity on each observation day. In the results section, these percentages will be referred to as percentage of time spent on each activity. The statistical analyses were performed on the percentage values obtained.

\section{Recording of Data}

During the experimental periods, milk yield (kg), milking frequency, passages through milking unit and selection gates, and intake of supplementary feeds in the barn were recorded automatically. Animals were weighed weekly throughout the experiment. Sampling of milk for analyses of protein, fat, and lactose contents was performed during 24-h periods; on each occasion, samples were collected from at least 2 milkings per cow. This process was performed before the experimental start and at the beginning and end of each experimental period. Energy-corrected milk was computed on the results of the analysis and on a 3-d average milk yield (kg) registered on the days around the sampling occasion.

Roughages were sampled each week day and were pooled over the experimental periods for laboratory analysis. Sward height was measured with a rising plate meter (Holmes, 1974), and sward was sampled twice weekly in the early season and once weekly later in the season in both pasture areas. Herbage samples were dried and pooled over the experimental periods. Samples were analyzed to determine content of DM (only silage) and CP according to conventional methods as described by Olsson et al. (1997), whereas NDF was analyzed according to Goering and Van Soest (1970). Herbage and silage contents of ME were determined by in vitro digestion as described by Lindgren (1979).

\section{Statistical Analyses}

Analysis of variance was performed on the data from each of the experimental periods with a standard General Linear Model using the statistical analysis system (SAS, 1989).

Average daily values of milk production, contents, and yields of milk fat and protein and feed intake data from each cow and period were computed and thereafter analyzed in a General Linear Model with treatment group, age (primiparous and multiparous), genetic selection line, and week of lactation as independent variables using production or content before the experimental start as a covariate in the model. The results are presented as least squares means together with standard errors (Tables 2 and 4). Interactions between treatment, age, selection line, and week of lactation data were not significant and were therefore excluded from the model.

Analysis of the distribution of the residuals was performed, and it was discovered that a normal distribution could be assumed for the behavior variables. However, one cow in group DP had to be removed from the data. This cow became frightened of entering the concentrate feeder at an early stage of the experiment, ate minimal concentrate, and was an outlier for behav- 
Table 2. Effect of distance to pasture and level of supplementary feeding on milk yield, milk composition, live weight change, and number of milkings and visits to the barn/d. Least squares means \pm standard errors for 3 treatment groups (near pasture [NP], distant pasture [DP], and DP + silage [DP + S]) are presented. Means with different superscripts differ $P<0.05$.

\begin{tabular}{|c|c|c|c|}
\hline & \multicolumn{3}{|c|}{ Treatment } \\
\hline & NP & $\mathrm{DP}$ & $\mathrm{DP}+\mathrm{S}$ \\
\hline \multicolumn{4}{|l|}{ Period 1 (Jun 5 to Jul 13) } \\
\hline Animals per treatment, no. & 15 & 15 & 15 \\
\hline $\mathrm{ECM},{ }^{1} \mathrm{~kg}$ & $30.5^{\mathrm{a}} \pm 0.9$ & $26.8^{\mathrm{b}} \pm 1.1$ & $28.0^{\mathrm{ab}} \pm 1.0$ \\
\hline Milk, ${ }^{1} \mathrm{~kg}$ & $29.1^{\mathrm{a}} \pm 0.7$ & $26.4^{\mathrm{b}} \pm 0.8$ & $26.1^{\mathrm{b}} \pm 0.7$ \\
\hline Fat, ${ }^{1} \%$ & $4.41 \pm 0.15$ & $4.21 \pm 0.16$ & $4.61 \pm 0.15$ \\
\hline Protein, ${ }^{1} \%$ & $3.41 \pm 0.05$ & $3.45 \pm 0.05$ & $3.53 \pm 0.05$ \\
\hline Milk fat, ${ }^{1} \mathrm{~kg}$ & $1.26^{\mathrm{a}} \pm 0.05$ & $1.08^{\mathrm{b}} \pm 0.06$ & $1.16^{\mathrm{ab}} \pm 0.05$ \\
\hline Milk protein, ${ }^{1} \mathrm{~kg}$ & $0.96^{\mathrm{a}} \pm 0.03$ & $0.87^{\mathrm{b}} \pm 0.03$ & $0.90^{\mathrm{ab}} \pm 0.03$ \\
\hline Milkings, no./d & $2.5^{\mathrm{a}} \pm 0.1$ & $2.3^{\mathrm{b}} \pm 0.1$ & $2.3^{\mathrm{b}} \pm 0.1$ \\
\hline Visits to barn, no./d & $6.1^{\mathrm{a}} \pm 0.3$ & $4.9^{\mathrm{b}} \pm 0.4$ & $4.3^{\mathrm{b}} \pm 0.3$ \\
\hline Cows fetched (per cowday²) & $0.02^{\mathrm{b}} \pm 0.03$ & $0.03^{\mathrm{ab}} \pm 0.03$ & $0.10^{\mathrm{a}} \pm 0.03$ \\
\hline${\text { Weight } \text { change }^{3}}^{3}$ & $3^{\mathrm{ab}} \pm 5$ & $-2^{\mathrm{a}} \pm 5.5$ & $17^{\mathrm{b}} \pm 5$ \\
\hline \multicolumn{4}{|l|}{ Period 2 (Aug 2 to 30$)$} \\
\hline Animals per treatment, ${ }^{4}$ no. & 10 & 6 & 12 \\
\hline $\mathrm{ECM},{ }^{1} \mathrm{~kg}$ & $26.9^{\mathrm{a}} \pm 1.2$ & $22.7^{\mathrm{b}} \pm 1.6$ & $25.6^{\mathrm{ab}} \pm 1.1$ \\
\hline Milk, ${ }^{1} \mathrm{~kg}$ & $26.4^{\mathrm{a}} \pm 0.7$ & $24.8^{\mathrm{ab}} \pm 1.2$ & $23.4^{\mathrm{b}} \pm 0.7$ \\
\hline Fat, ${ }^{1} \%$ & $4.62 \pm 0.13$ & $4.48 \pm 0.18$ & $4.93 \pm 0.13$ \\
\hline Protein, ${ }^{1} \%$ & $3.62 \pm 0.05$ & $3.48 \pm 0.07$ & $3.67 \pm 0.06$ \\
\hline Milk fat, ${ }^{1} \mathrm{~kg}$ & $1.12 \pm 0.05$ & $0.96 \pm 0.07$ & $1.08 \pm 0.05$ \\
\hline Milk protein,${ }^{1} \mathrm{~kg}$ & $0.88^{\mathrm{a}} \pm 0.03$ & $0.73^{\mathrm{b}} \pm 0.05$ & $0.81^{\mathrm{ab}} \pm 0.03$ \\
\hline Milkings, no./d & $2.5^{\mathrm{a}} \pm 0.1$ & $2.5^{\mathrm{a}} \pm 0.1$ & $2.1^{\mathrm{b}} \pm 0.1$ \\
\hline Visits to barn, no./d & $5.4^{\mathrm{a}} \pm 0.4$ & $4.6^{\mathrm{ab}} \pm 0.7$ & $3.9^{\mathrm{b}} \pm 0.4$ \\
\hline Cows fetched (per cowday ${ }^{2}$ ) & $0.03 \pm 0.04$ & $0.01 \pm 0.06$ & $0.15 \pm 0.04$ \\
\hline Weight change $^{3}$ & $5^{\mathrm{ab}} \pm 5$ & $-8^{a} \pm 7$ & $12^{\mathrm{b}} \pm 5$ \\
\hline
\end{tabular}

${ }^{\mathrm{a}, \mathrm{b}}$ Means within rows with differing superscripts are significantly different $(P<0.05)$.

${ }^{1}$ Energy-corrected milk (ECM), fat and protein percentage, and amounts are based on milk sampling from milkings in the barn during $24 \mathrm{~h}$ and registration of milk yield during $72 \mathrm{~h}$ at the end of the period. Milk $(\mathrm{kg})$ is based on daily observations during the entire period.

${ }^{2}$ Cowday $=$ Number of cows times number of days in the period.

${ }^{3}$ Live weight change between pasture let out (May 17) and the end of the period.

${ }^{4}$ Several animals entered their dry period during the summer.

ior. Therefore, she was removed completely from the experiment (i.e., both from production and behavior data analysis). Thus, only 29 animals were in the statistical analysis of the behavior data for observation $d 1$ to 5 . A number of cows were dried after mid July, yielding only 28 and 21 animals for the analysis of observation $d 6$ and 7, respectively.

Analysis of variance was performed on behavior observations in a similar manner as had been done with production and feed intake data using treatment group, age, selection line and week of lactation as independent variables. Nonsignificant variables and interactions were excluded, and a model with only treatment and age as independent variables was used for the final analysis of the behavior observations (Figures 2 through 5).

\section{RESULTS}

\section{Recordings in the Milking Unit and Live Weight Change}

The results of the statistical analysis of the data from the two experimental periods are presented in Table
2. Compared with treatment group DP, milk yield of animals in treatment group NP was significantly higher during Period 1 ( $\mathrm{kg}$ of milk and $\mathrm{kg}$ of ECM) and during Period 2 ( $\mathrm{kg}$ of ECM). Milk production was similar among animals in these two groups $(30.5 \pm 1.4 \mathrm{~kg}$ of $\mathrm{ECM} / \mathrm{d}$ vs. $29.2 \pm 1.1 \mathrm{~kg}$ of ECM/d) when the animals were let out onto pasture. However, during the first 4 wk on pasture, milk production of cows in the NP group increased, whereas there was a slight decrease in production of cows in the DP group. During the rest of the season the difference between the two groups was maintained on a similar level. No significant differences in milk fat or milk protein contents were found between treatments.

Animals in treatment group NP also had a significantly higher milking frequency and a larger number of visits to the barn compared with the other treatments. During Period 2, milking frequency was significantly lower for the animals in group $\mathrm{DP}+\mathrm{S}$ compared with the two other treatments. There was large individual variation in the number of times cows had to be fetched and brought to milking manually; 2 cows were responsi- 
Table 3. Mean $( \pm \mathrm{SD})$ sward height of pastures near (NP) and distant (DP) and chemical composition of pasture and roughage supplements during the 2 experimental periods. Pastures were grass-dominated swards (Kentucky bluegrass and meadow fescue).

\begin{tabular}{|c|c|c|c|c|}
\hline & \multicolumn{2}{|c|}{ Pasture herbage } & \multicolumn{2}{|c|}{ Supplementary roughages } \\
\hline & NP & DP & Grass silage & Hay \\
\hline \multicolumn{5}{|l|}{ Period 1(Jun 5 to July13) } \\
\hline Sward height, $\mathrm{cm}$ & $12.9(1.8)$ & $11.0(1.7)$ & $\ldots$ & $\ldots$ \\
\hline Herbage mass, $\mathrm{kg}$ of $\mathrm{DM} / \mathrm{ha}^{1}$ & 1960 & 1590 & & \\
\hline DM, \% & $\ldots$ & $\ldots$ & $57.0(6.0)$ & $89.4(2.3)$ \\
\hline $\mathrm{CP}, \%$ of $\mathrm{DM}$ & $14.7(0.9)$ & $16.0(2.9)$ & $14.9(0.1)$ & $11.5(0.4)$ \\
\hline $\mathrm{NDF}, \%$ of DM & $52.7(0.9)$ & $45.8(5.2)$ & $43.3(0.5)$ & $58.2(0.6)$ \\
\hline Energy, $\mathrm{mJ}$ of $\mathrm{ME}^{2} / \mathrm{kg}$ of $\mathrm{DM}$ & $10.6(0.4)$ & $10.8(0.3)$ & $10.9(0.0)$ & $10.7(0.1)$ \\
\hline \multicolumn{5}{|l|}{ Period 2 (Aug 2 to 30 ) } \\
\hline Sward height, $\mathrm{cm}$ & $12.1(2.2)$ & $11.9(3.1)$ & $\ldots$ & $\ldots$ \\
\hline Herbage mass, $\mathrm{kg}$ of $\mathrm{DM} / \mathrm{ha}^{1}$ & 2330 & 2290 & & $\cdots$ \\
\hline $\mathrm{DM}, \%$ & $\ldots$ & $\ldots$ & $34.7(1.6)$ & $87.6(0.6)$ \\
\hline $\mathrm{CP}, \%$ of $\mathrm{DM}$ & $20.0(0.3)$ & $20.7(0.2)$ & $13.2(0.2)$ & $9.1(1.9)$ \\
\hline $\mathrm{NDF}, \%$ of DM & $47.4(1.0)$ & $38.3(0.8)$ & $50.9(1.1)$ & $61.6(1.8)$ \\
\hline Energy, $\mathrm{mJ}$ of $\mathrm{ME} / \mathrm{kg}$ of $\mathrm{DM}$ & $10.2(0.04)$ & $10.7(0.04)$ & $10.7(0.2)$ & $10.1(0.6)$ \\
\hline
\end{tabular}

ble for approximately $40 \%$ of the times cows were fetched during both periods. However, treatment group $\mathrm{DP}+\mathrm{S}$ included 70 and $77 \%$ of the total fetched cows during Periods 1 and 2, respectively, and the difference between treatment group $\mathrm{DP}+\mathrm{S}$ and the other two groups was near significance $(P<0.1)$ during Period 2 . A tendency $(P<0.1)$ for a difference in milk yield (ECM) between group NP and $\mathrm{DP}+\mathrm{S}$ and a difference in weight change between group NP compared with DP $+\mathrm{S}$ (Table 2) was observed during Period 1.

Compared with older cows, first lactation cows had a significantly higher number of daily milkings and visits to the barn, $+0.2(P<0.01)$ and $+1.2(P<0.05)$, respectively, during Period 1. First lactation cows also passed significantly $(P<0.05)$ more often $(+1.1$ times/ d) through the selection gates in the barn during both Periods 1 and 2. However, no significant difference in milk production was found between animals in their first lactation and older cows. Cows in group DP $+\mathrm{S}$ had a significant weight gain during Period 1 compared with that for cows in group DP. On an overall level, there was also a significant difference in weight change between first lactation and multiparous cows during Period 1, with a weight gain of approximately $13 \mathrm{~kg}$ in multiparous cows at the end of Period 1 compared with a weight loss of $1 \mathrm{~kg}$ for cows in first lactation.

To ensure that the results were not affected by a small number of cows in very early or very late stages of lactation, an analysis was performed on a subset of data where cows before 8 wk in lactation or after 40 wk in lactation were removed from the dataset; similar results were obtained and are not presented here.

\section{Pasture and Supplementary Feed}

Weather conditions during the experiment were favorable, and there was sufficient herbage of good quality available in both pasture areas throughout the season. Sward heights and the chemical composition of the pasture in the two pasture areas are presented in Table 3 together with the chemical composition of supplementary roughages.

As can be seen from the table, sward height during Period 1 was slightly lower and pasture quality was somewhat higher on the DP area, with higher energy and CP content and lower content of NDF.

The analysis of the intake of supplements in the barn showed no significant difference in the intake of concentrate, silage, or hay between treatment groups NP and DP during the two experimental periods (Table 4). Also, no difference was observed between these two groups with regard to intake of ME from supplements. Because of ad libitum supplementation, the treatment group DP $+\mathrm{S}$ had a significantly higher intake of silage and of ME from supplements compared with the two other groups. However, none of the groups covered their energy requirements with intake from supplements only. To cover energy requirements for the achieved milk production level, the cows in groups NP, DP, and DP $+\mathrm{S}$ would have needed a pasture intake of approximately $8.8,7.2$, and $4.1 \mathrm{~kg}$ of DM/d per cow, respectively, during experimental Period 1 and $8.2,6.6$, and $5.0 \mathrm{~kg}$ of $\mathrm{DM} / \mathrm{d}$ per cow, respectively, during Period 2. Animals in their first lactation had a significantly $(P<0.05)$ lower intake of silage compared with older cows, a dif- 
Table 4. Least squares means ( \pm SE) for average daily intake per cow of supplementary feeds in the treatment groups (near pasture $[\mathrm{NP}]$, distant pasture $[\mathrm{DP}]$, and $\mathrm{DP}+$ silage $[\mathrm{DP}+\mathrm{S}]$ ) during the 2 experimental periods.

\begin{tabular}{lccc}
\hline & \multicolumn{3}{c}{ Treatment } \\
\cline { 2 - 4 } & $\mathrm{NP}$ & $\mathrm{DP}$ & $\mathrm{DP}+\mathrm{S}$ \\
\hline Period 1 (Jun 5 to Jul 13) & & \\
$\quad$ Concentrates, $\mathrm{kg}$ & $7.4 \pm 0.3$ & $6.9 \pm 0.4$ & $6.5 \pm 0.3$ \\
Silage, kg of DM & $2.7^{\mathrm{b}} \pm 0.3$ & $2.9^{\mathrm{b}} \pm 0.3$ & $7.2^{\mathrm{a}} \pm 0.3$ \\
Hay, kg of DM & $0.7^{\mathrm{a}} \pm 0.05$ & $0.6^{\mathrm{ab}} \pm 0.05$ & $0.4^{\mathrm{b}} \pm 0.05$ \\
Supplemental intake, mJ/d & $127^{\mathrm{b}} \pm 5$ & $121^{\mathrm{b}} \pm 5$ & $162^{\mathrm{a}} \pm 5$ \\
Period 2 (Aug 2 to 30) & & & \\
Concentrates, $\mathrm{kg}$ & $7.7^{\mathrm{a}} \pm 0.4$ & $6.8^{\mathrm{ab}} \pm 0.7$ & $6.3^{\mathrm{b}} \pm 0.4$ \\
Silage, kg of DM & $1.9^{\mathrm{b}} \pm 0.3$ & $1.8^{\mathrm{b}} \pm 0.2$ & $5.7^{\mathrm{a}} \pm 0.2$ \\
Hay, kg of DM & $0.4^{\mathrm{a}} \pm 0.04$ & $0.4^{\mathrm{ab}} \pm 0.06$ & $0.2^{\mathrm{b}} \pm 0.04$ \\
Supplemental intake, mJ/d & $116^{\mathrm{b}} \pm 5$ & $105^{\mathrm{b}} \pm 9$ & $139^{\mathrm{a}} \pm 5$ \\
\hline
\end{tabular}

${ }^{\mathrm{a}, \mathrm{b}}$ Means within rows with differing superscripts are significantly different $(P<0.05)$.

${ }^{1}$ Total amount of concentrates (concentrates in milking unit + concentrate feeder).

ference of 0.9 and $0.5 \mathrm{~kg}$ of DM during Periods 1 and 2 , respectively.

\section{Animal Behavior}

Analysis of the data from the behavior observations showed that cows in all treatment groups had a fairly uniform behavior during the first one-half of the grazing season, i.e., observation $d 1$ to 5 . However, after mid July, a change in behavior was observed in the groups. Therefore, means for observation d 1 to 5 are presented, whereas observation $d 6$ and 7 are presented separately in tables and figures.

During the first 5 observation days, the weather was mostly warm and sunny with occasional short showers. Continuous rain only occurred during 1 of the 6 -h observation periods during those $5 \mathrm{~d}$. It rained during all periods of observation on $d 6$, and the cow tracks became very muddy and slippery in certain places. During observation $d 7$, the weather was again sunny with only occasional showers.

Location choice of cows. During the first 5 observation days, animals in treatment group NP spent $68 \%$ of their time outdoors (Figure 2), whereas the corresponding percentage for animals in both groups grazing on DP was only $44 \%(P<0.001)$. The time spent outdoors seemed to be fairly stable during periods of good weather. However, rainy weather likely had an effect, as can be seen on observation d 6 when animals in all groups decreased the time they spent outdoors.

During observation d 1 to 5 (Period 1), animals in pasture group NP spent $4 \%$ of their time on the cow track; animals in groups $\mathrm{DP}$ and $\mathrm{DP}+\mathrm{S}$ spent approximately twice as much time there $(P<0.01)$. During the same period, primiparous cows spent significantly $(P<$ $0.05)$ more time on the cow track than older cows, 8 and 5\%, respectively. During observation d 7 (Period
2), animals in group NP continued to spend approximately the same amount of time on the cow track, whereas animals in treatment groups $\mathrm{DP}$ and $\mathrm{DP}+\mathrm{S}$ dramatically increased the time spent on the cow track to around $32 \%$ of their time.

Although there was a large difference in the level of silage allowance between group $\mathrm{DP}+\mathrm{S}$ and the other two groups, the cows in the 3 groups spent the same amount of time in the feeding area, 10 to $12 \%$ of their time during observation d 1 to 5 and slightly more during observation $d 6$. However, there was a significant $(P<0.01)$ effect of age during observation $\mathrm{d} 6$, as primiprous cows were in the feeding area $21 \%$ of the time, whereas multiparous cows were there only $14 \%$ of the time. No differences were observed between groups in time spent in the milking unit or time spent waiting in front of the milking unit; cows spent 12 to $14 \%$, $16 \%$, and 18 to $22 \%$ of their time in these areas during observation d 1 to 5,6 , and 7, respectively.

Lying down. Cows in all treatment groups spent 42 to $46 \%$ of their time lying down. However, there was a large difference between treatments as to where they rested. Averaged over 7 observation days, cows in group NP spent $80 \%$ of their total lying time out on pasture. In contrast, cows on the distant pasture seemed to prefer to lie down indoors (Figures 3 and 4) and during the first 6 observation days, these groups spent only $29 \%$ of their total lying time resting on the pasture. However, during observation $d 7$, the cows in groups $\mathrm{DP}$ and DP + S had drastically decreased their total time on pasture. They walked out of the barn, and, instead of continuing to the pasture, they stayed on the cow track just outside the barn, many of them lying and resting there, which had not occurred during the first 6 observation days. Thus, during observation $d 7$ (August), these treatment groups spent around 20\% of 
their time lying on the cow track, which was approximately one-half of their total lying time.

Although there was a difference between groups as to where the animals rested, there was evidence of synchronization of the times of lying indoors and outdoors within and between treatment groups. Data from observation $d 1$ to 5 showed that the animals were fairly active throughout the day with an even proportion of animals lying down. At around $1700 \mathrm{~h}$, a peak in lying indoors occurred. Thereafter, animals seemed to have left the barn to graze for a period in the evening and then rested out on the pasture, where a large proportion of the cows were observed to be lying down between 2300 and $0300 \mathrm{~h}$. Toward the latter part of this period, the animals went back to the barn, where they continued to lie down. Resting indoors reached a peak for all groups at around $0500 \mathrm{~h}$. After that, the animals became active again, going to the milking unit and feeding stations and then out onto the pasture to graze.

Grazing. During the first 5 observation days, the cows in the 3 treatment groups spent approximately $20 \%$ of their time grazing (Figure 5). No differences between groups were found. During fairly rainy weather on observation $d 6$, the animals in groups DP and $\mathrm{DP}+\mathrm{S}$ decreased their grazing time to 9 and $7 \%$, respectively, whereas animals in group NP continued to spend $20 \%$ of their time grazing. The same pattern was seen during observation $d 7$, although the weather during that period was pleasant with only occasional showers. The difference in grazing time between groups on the 2 pasture areas was significant $(P<0.01)$ during observation $\mathrm{d} 6$ and 7 .

There was also synchronization of grazing behavior. Data from observation $d 1$ to 5 showed that each of the 3 groups had a peak in grazing activity occurring sometime between 0900 and $1300 \mathrm{~h}$, with 30 to $40 \%$ of the cows grazing at one time. A peak in grazing activity for all groups was also observed in the evening at around $2100 \mathrm{~h}$ with 50 to $60 \%$ of the cows grazing at that time. Observation $d 1$ to 5 took place during June and early July when it is very light in the evenings.

\section{DISCUSSION}

Cows that had to walk a distance of $260 \mathrm{~m}$ to the pasture (group DP) had a lower milk yield (4 kg of ECM) and a lower milking frequency during Period 1 (0.2 milkings/d) compared with cows that had a distance of $50 \mathrm{~m}$ between barn and pasture (group NP). A possible explanation for the difference in production could be that the longer walking distance increased energy requirement of group DP. However, only part of the lower milk production of group DP can be explained by the higher energy requirement for walking. The difference

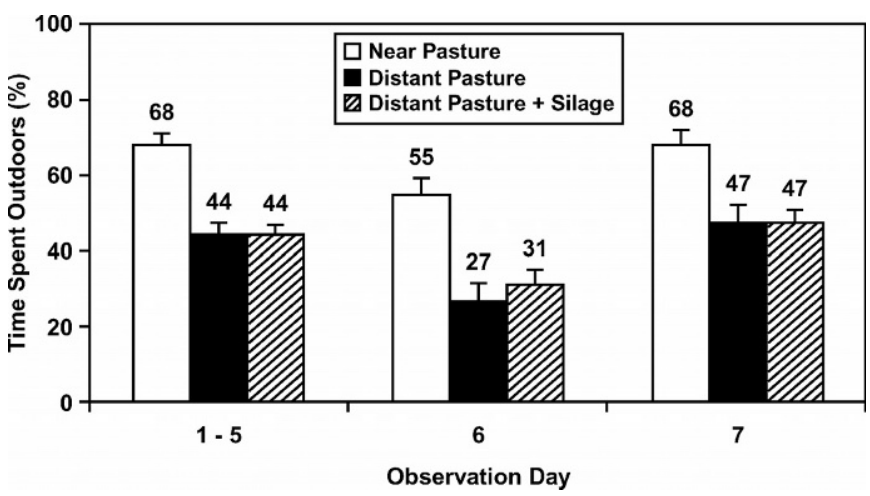

Figure 2. Average time cows in the treatment groups (near pasture, distant pasture, and distant pasture + silage) spent outdoors (least squares means). Differences between NP and other groups were significant $(P<0.001)$ during observation $d 1$ to $5(\mathrm{n}=29)$ and $\mathrm{d} 6$ $(\mathrm{n}=28)$ and were significant $(P<0.01)$ during $d 7(\mathrm{n}=21)$.

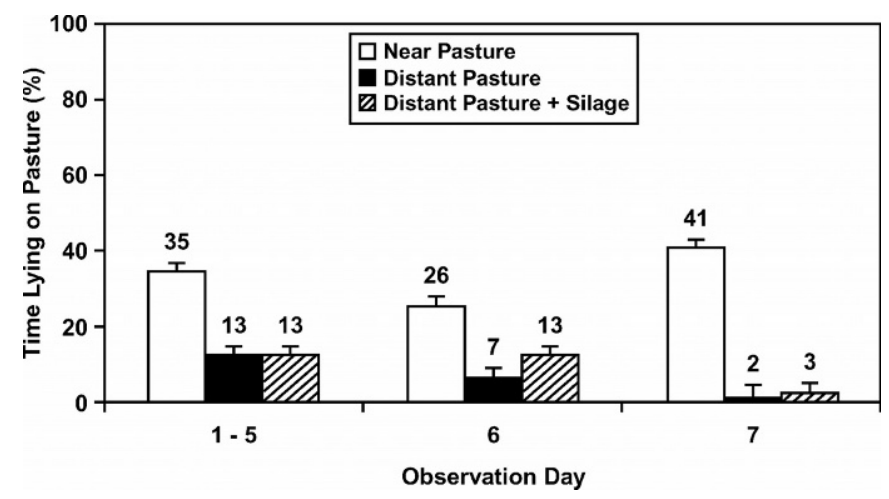

Figure 3. Average time cows in the treatment groups (near pasture, distant pasture, and distant pasture + silage) spent lying in the pasture (least squares means). Differences between NP and other groups were significant $(P<0.001)$ during observation $\mathrm{d} 1$ to $5(\mathrm{n}=$ $29)$, d $6(n=28)$, and d $7(n=21)$.

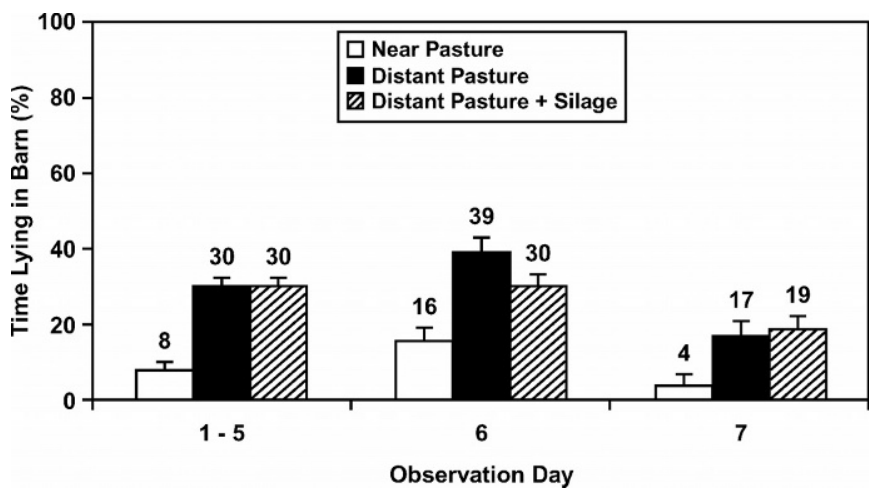

Figure 4. Average time cows in the treatment groups (near pasture, distant pasture, and distant pasture + silage) spent lying in the barn (least squares means). Differences between NP and other groups were significant during observation $\mathrm{d} 1$ to $5(\mathrm{n}=29 ; P<0.001)$, d $6(\mathrm{n}=28 ; P<0.01)$, and d $7(\mathrm{n}=21 ; P<0.05)$. 


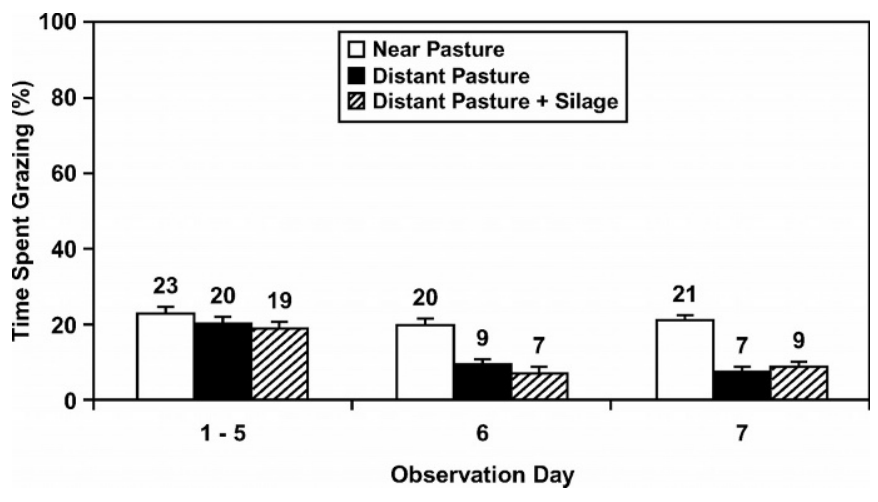

Figure 5. Average time cows in the treatment groups (near pasture, distant pasture, and distant pasture + silage) spent grazing (least squares means). No significant differences were found between groups during observation d 1 to $5(\mathrm{n}=29)$. The difference between NP and other groups was significant $(P<0.001)$ during observation d $6(n=28)$ and $7(n=21)$.

in walking distance to the nearest and to the most distant point of the pasture was 210 and $520 \mathrm{~m}$, respectively, giving an average difference of $365 \mathrm{~m}$ between the groups, i.e. ( $730 \mathrm{~m}$ to the pasture and back). Assuming that the cows walked to the pasture 2 to 3 times/ $\mathrm{d}$ during Period 1 , the difference in walking distance between the groups would be almost $2 \mathrm{~km}$. According to the NRC (2001), the increase in energy requirement for walking $2 \mathrm{~km} / \mathrm{d}$ is around $5 \%$ of maintenance, corresponding to approximately 0.5 to $1 \mathrm{~kg}$ of milk. During Period 2, cows on DP decreased their grazing time and spent more time closer to the barn; therefore, the difference between groups NP and DP in energy requirement for walking was probably even smaller than during Period 1.

It is possible that part of the difference in milk production between groups can be explained by differences in pasture intake immediately after cows had been allowed access to pasture. Differences in milk yields between groups were established during the first weeks on pasture. Animals in treatment group NP seemed to adapt rapidly to the grazing situation and responded to the high quality feed that was available with an increase in milk yield. In contrast, the animals on DP, especially those with the lower supplementation level, responded with a decrease in milk yield. However, no behavior observations were performed during the first weeks on pasture, and, therefore, the hypothesis of a difference in grazing time was not possible to verify.

The treatment with a high level of silage supplementation $(\mathrm{DP}+\mathrm{S})$ had no favorable effect on milking frequency and only a limited effect on milk production. Because the pasture offers a cheap high quality feed, there seems to be no reason to offer large amounts of roughage supplements in the barn when pasture is available. The effect of supplementary forage on herbage intake was summarized in a review by Phillips (1988). Phillips concluded that although forage supplements may be favorable at limited herbage allowance, the case is different when herbage is available ad libitum. A similar discussion on the effect of forage supplementation on pasture is found in a more recent review by Bargo et al. (2003). When cows are given forage supplements at a high pasture allowance, substitution rate tends to be high. In the review, it was concluded that no effect on milk production was obtained by offering forage supplements to grazing cows when substitution rate was high, which is in accordance with the results from this experiment. With the very limited or negative response obtained here, this management practice seems to be uneconomical.

During Period 1, the animals on treatment NP had a significantly higher milking frequency and more visits to the barn compared with animals on DP with the same level of supplementary feeding. However, these differences between NP and DP in milking frequency and in the number of visits to the barn decreased and were non-significant during Period 2. The reason for this was probably that the animals in group DP did not walk out to the pasture as much during Period 2, but spent more time on the cow track just outside the barn. Thus, the average distance from the milking unit decreased, and it seems likely that this could explain the lack of difference in milking frequency during the second experimental period. In contrast to the results for Period 1 presented here, Ketelaar-de Lauwere et al. (2000) found no differences in milking frequency when cows grazed at a distance of $150 \mathrm{~m}$ compared with 350 $\mathrm{m}$ with a daily grazing time of $15 \mathrm{~h}$.

During observation $\mathrm{d} 1$ to 5 , animals in the 3 treatment groups spent $19 \%(\mathrm{DP}+\mathrm{S}), 20 \%(\mathrm{DP})$, and $23 \%$ (NP) of their time grazing, which would correspond to 4.6 to $5.5 \mathrm{~h}$ of grazing. During observation d 6 and 7 , grazing time in group NP continued to be similar. However, grazing time for groups on $\mathrm{DP}$ and $\mathrm{DP}+\mathrm{S}$ decreased during the second half of the grazing season and were only 1.7 to $2.2 \mathrm{~h}$ during observation $\mathrm{d} 6$ and 7. Experimental data compiled in a review article by Krysl and Hess (1993) showed a range in grazing time between 6 and $13 \mathrm{~h} / \mathrm{d}$ in the reviewed experiments, and Rook and Yarrow (2002) reported a similar range, between 7 and $12 \mathrm{~h} / \mathrm{d}$. Grazing time was between 8 to $9 \mathrm{~h}$ on a grazing treatment where levels of concentrate supplementation and pasture allowance were even higher than in the present experiment (Bargo et al., 2002). Thus, it can be concluded that grazing hours were low (Period 1) or very low (DP; Period 2) compared with data from grazing management in conventional milking systems. However, in conventional grazing 
management, the cows have a very limited choice of location and activity, and the cows are herded to the pasture and have to stay there until they are fetched to be milked. In contrast, a cow in an automatic milking system has a choice between staying in the barn (where she can be milked, eat supplements, drink, or rest) and going to the pasture (where she can graze, rest, and perhaps drink). The choice of each cow in an automatic milking system is influenced by many factors such as weather, concentrate supply system, gates and cow traffic in the barn, drinking water location, distance to the pasture, and location of the other cows in the herd. Clearly, there is a large difference between a cow in an automatic milking system during the grazing season and conventional grazing management. Therefore, it is not surprising that grazing hours in this experiment differ from what has been reported earlier. Experimental data from grazing $24 \mathrm{~h}$ combined with automatic milking is limited, but, in an experiment with different grazing hours, Ketelaar-de Lauwere et al. (1999) reported 6.3 and $5.7 \mathrm{~h}$ of total foraging time (feeding gate or at pasture), respectively, for primiparous and multiparous cows on a 24 -h grazing regimen. Taking into consideration that these data include time at feeding gates, these values are similar to the grazing hours in Period 1. Although the grazing hours during the experiment were low, the diurnal grazing pattern was similar to what has been reported elsewhere (Gibb et al., 1997; O'Conell et al., 1989).

Early season pasture is known to have a high nutritive value, and grazing animals are generally eager to graze in the beginning of the season (Spörndly and Burstedt, 1996). Thus, during Period 1, animals in groups DP and DP $+\mathrm{S}$ were prepared to walk the longer distance. However, as the season progressed, fresh grass was no longer a new feed; therefore, motivation to walk the longer distance decreased. The very low grazing hours for animals on the DP in Period 2 seemed to be a response to the long distance to the pasture. Although the weight loss of group DP indicated that the animals were underfed during this period, cow motivation to walk to the DP was low. The change in grazing behavior of groups DP and DP + S clearly illustrated the challenge of combining automatic milking and grazing. The farmer must be observant of changes in cow behavior and adapt management to ensure sufficient nutrient intake that maintains a high production level. In contrast to the results obtained here, in the experiment of Ketelaar-de Lauwere et al. (2000) there seemed to be no consistent connection between grazing time and distance to pasture, although some differences were observed between different periods. The fact that the cows in the present experiment could not see the DP from the area just outside the barn may be one possible expla- nation of the difference in results between the experiments.

During the whole season, a large difference was observed between groups NP and DP in the time they spent lying down on pasture and in the barn (Figures 3 and 4). Cows that can choose between lying down in the barn or out on pasture have, in several experiments, preferred to lie down on the pasture (Ketelaar-de Lauwere et al., 1999; Krohn et al., 1992). The significant difference between groups in the time animals spent lying down on pasture indicated that the distance was an obstacle for the groups on the DP. The fact that the animals in these groups started to lie down on the cow track during Period 2 (observation d 7) seems to strengthen this conclusion.

The treatments were imposed on the 3 groups of animals simultaneously. The large seasonal variation in grazing conditions in most parts of Scandinavia makes it unsuitable to subject the animals to the treatments in periods over time as was done by Ketelaar-de Lauwere et al. (2000). However, when animals subjected to different treatments cannot be physically separated, there is a risk of synchronization of behavior between different treatments. This was especially obvious for the animals in groups DP and DP $+\mathrm{S}$ that shared the same pasture area and the same feeding area in the barn. The behavior of the animals in these two groups was similar throughout the grazing season, and it is possible that the behavior would have differed more if they had been separated from each other.

\section{CONCLUSIONS}

This experiment has shown that cows in an automatic milking system grazing a pasture area just $50 \mathrm{~m}$ from the barn (group NP) had a higher milk production $(+4$ $\mathrm{kg}$ of EMC) compared with cows grazing at a distance of $260 \mathrm{~m}$ (group DP). The cows with the shorter distance also had a higher milking frequency during the first half of the grazing season (+0.2 milkings/d). In the early season, the cows on the distant pasture spent the same amount of time grazing, but as the season progressed, animals grazing on the DP decreased their grazing time to only a few hours per day, while animals on the near pasture continued to graze as before. For the farmer who wants to combine automatic milking and grazing, it is important to localize the grazing area as close to the barn as possible and to observe cow behavior to ensure that nutrient intake of animals is sufficient to maintain production level.

The experiment has also shown that an ad libitum grass silage supplementation (group DP $+\mathrm{S}$ ) did not lead to a higher milk production or a higher milking frequency compared with a supplementation level of 3 
$\mathrm{kg}$ of DM from silage (group DP). During the latter part of the grazing season, animals in group $\mathrm{DP}+\mathrm{S}$ even had a significantly lower milking frequency compared with animals in group DP. Therefore, a high roughage supplementation level does not seem recommendable when sufficient, good quality pasture is available. The cost for harvesting, storing, and feeding of supplements can be reduced if the farmer makes use of the potential of high quality pasture feed.

One of the important findings of this experiment is that cows can change their behavior as the season progresses, although management and pasture conditions remain essentially the same. Automatic milking is a new management system where the choice of the cow is an important factor that needs to be taken into consideration. The challenge for the herdsman working with an automatic milking system during the pasture season is to observe and understand the behavior of the cow and take management measures to ensure a sufficient nutrient intake and a maintained production throughout the pasture season.

\section{ACKNOWLEDGMENTS}

This experiment was financed by the Swedish Farmer's Foundation for Agricultural Research, which is gratefully acknowledged.

\section{REFERENCES}

Åkerlind, M., K. Holtenius, J. Bertilsson, and M. Emanuelson. 1999. Milk composition and feed intake in dairy cows selected for high or low milk fat percentage. Livest. Prod. Sci. 59:1-11.

Bargo, F., L. D. Muller, J. E. Delahoy, and T. W. Cassidy. 2002. Milk response to concentrate supplementation of high producing dairy cows grazing at two pasture allowances. J. Dairy Sci. 85:17771792.

Bargo, F., L. D. Muller, E. S. Kolver, and J. E. Delahoy. 2003. Invited review: Production and digestion of supplemented dairy cows on pasture. J. Dairy Sci. 86:11-42.

Goering, H. K., and P. J. Van Soest. 1970. Forage Fiber Analyses (Apparaus, Reagents, Procedures and Some Applications). Agric. Handbook No. 379. ARS-USDA, Washington, DC.

Gibb, M. J., C. A. Huckle, R. Nuthall, and A. J. Rook. 1997. Effect of sward surface height on intake and grazing behavior by lactating Holstein Friesian cows. Grass Forage Sci. 52:309-321.

Gustafson, G. M. 1993. Effects of daily exercise on the health of tied dairy cows. Prev. Vet. Med. 17:209-223.
Holmes, C. W. 1974. The Massey grass meter. Pages 26-30 in Dairy Farmer Annual. Massey Univ., New Zealand.

Ketelaar-de Lauwere, C. C., A. H. Ipema, E. N. J. van Ouwerkerk, M. M. W. B. Hendriks, J. H. M. Metz, J. P. T. M. Noordhuizen, and W. G. P. Schouten. 1999. Voluntary automatic milking in combination with grazing dairy cows. Milking frequency and effects on behaviour. Appl. Anim. Behav. Sci. 64:91-109.

Ketelaar-de Lauwere, C. C., A. H. Ipema, C. Lokhorst, J. H. M. Metz, J. P. T. M. Noordhuizen, W. G. P. Schouten, and A. C. Smits. 2000. Effect of sward height and distance between pasture and barn on cows' visits to an automatic milking system and other behaviour. Livest. Prod. Sci. 65:131-142.

Krohn, C. C., L. Munksgaard, and B. Jonasen. 1992. Behaviour of dairy cows kept in extensive (loose housing/pasture) or intensive (tie stall) environments. I. Experimental procedure, facilities, time budgets-Diurnal and seasonal conditions. Appl. Anim. Behav. Sci. 34:37-47.

Krysl, L. J., and B. W. Hess. 1993. Influence of supplementation on behavior of grazing cattle. J. Anim. Sci. 71:2546-2555.

Lindgren, E. 1979. Nutrient content in roughages determined in vitro and with different laboratory methods (in Swedish with English summary). Rep. 45, Dep. Anim. Nutr. Manage., Swedish Univ. Agric. Sci., Uppsala.

Mathijs, E. 2000. Public acceptance of robot milking. Pages 243247 in Robotic Milking, Proc. Int. Symp. H. Hogeveen and A. Meijering, eds. August 17-19 2000, Lelystad, The Netherlands.

National Research Council. 2001. Page 20 in Nutrient Requirements of Dairy Cattle. 7th rev. ed. Natl. Acad. Sci., Washington, DC.

O'Conell, J., P. S. Giller, and W. Meany. 1989. A comparison of dairy cattle behavioural patterns at pasture and during confinement. Ir. J. Agric. Res. 28:65-78.

Olsson, G., M. Emanuelson, and H. Wiktorsson. 1997. Effects on milk production and health of dairy cows by feeding different rations of concentrate/forage and additional fat before calving. Acta Agric. Scand. A Anim. Sci. 47:91-105.

Phillips, C. J. C. 1988. The use of conserved forage as a supplement for grazing dairy cows. Grass Forage Sci. 43:215-230.

Prescott, N. B., T. T. Mottram, and A. J. R. Webster. 1998. Relative motivation of dairy cows to be milked or fed in a Y-maze and an automatic milking system. Appl. Anim. Behav. Sci. 57:23-33.

Rook, A. J., and N. H. Yarrow. 2002. Incorporating grazing behaviour measurements in models to predict herbage intake by grazing dairy cows. Grass Forage Sci. 57:19-24.

SAS User's Guide. Statistics. Version 6.12, Edition 1989. SAS Inst., Inc., Cary, NC.

Sjaunja, L.-O., L. Baevre, L. Junkkarinen, J. Pedersen, and J. Setälä. 1990. A Nordic proposal for an energy corrected milk (ECM) fromula. In ICEPMA, Paris, France.

Spörndly, E., and E. Burstedt. 1996. Effects of sward height and season on herbage intake of strip grazed dairy cows. Acta Agric. Scand. Sect. A Anim. Sci. 46:87-96.

van Dooren, H. J. C., E. Spörndly, and H. Wiktorsson. 2002. Automatic milking and grazing. Applied grazing strategies. Deliverable D25, EU project "Implications of the introduction of automtatic milking on dairy farms (QLK5-2000-31006)" [Online]. Available at: http:// www.atutomaticmilking.nl. Accessed Feb. 26, 2002. 